\title{
Şiirsel Yapı Açısından Çocuk Şiirleri
}

\author{
Children's Poetry with Regard to Poetic Structure
}

\section{Nihat BAYAT* ${ }^{*}$ \\ Gökhan ÇETINKAYA**}

Öz: Bu çalışmada çocuk yazını kapsamında ele alınan çocuk şiirleri kavramı irdelenmiştir. Öncelikle şiir türü, çağdaş dil kuramları ve göstergebilim verilerine dayalı olarak ortaya çıkan şiirbilimin ilkeleri açısından betimlenmiş ve buna göre şiirin doğal dil üstünde yapılan özel bir biçimleme sonucunda ortaya çıktığı anlatılmıştır. Şiir dilinin tözü olarak ele alınan doğal dilde iletişimsel boyutun öncelikli olmasına karşın şiirsel dilde ileti bastırılır. Şiir, iletinin bastırılması yoluyla dilin ve sözcüklerin birer alım nesnesine dönüşmesi sonucunda yapılanır. Ancak çocuk yazınının bir türü olarak değerlendirilen çocuk şiirlerinde eğitme ve öğretme temel amaç olarak ele alındığından ileti öne çıkarılır. İletinin okura aktarılması incelendiğinde şiirsel nitelikler kaybolmaya başlar. Yalnızca belli bir ölçü ve uyakla yazılmış dizeli anlatımlar, söz konusu betiklerin şiir olmasını sağlamakta yetersiz kalır. Dolayısıyla çocuk okurlar, birçok çocuk şiirini okurken gerçekte şiirsel bir deneyim yaşamaz. Bunun yerine şiirsel olmayan metinlere özgü iletişimsel bir edim içinde bulunurlar. Bu durum, çocukların şiirsel ve yazınsal bilinç geliştirmelerine engel olur. Bu nedenle çocuk yazını kapsamında ele alınan çocuk şiirlerinin öncelikle şiirsel niteliklere sahip olması ve oluşturdukları yeni anlamlama dizgesinin çocuklar tarafindan şiirsel bir okumaya olanak tanıyacak biçimde üretilmesi önerilmiştir.

Anahtar sözcükler: Şiir, Çocuk Şiiri, Çocuk Yazını

Abstract: In this research the concept of children's poetry as part of children's literature is scrutinized. Firstly, poetry is described in terms of poetics that has arisen on the basis of contemporary linguistic theories and semiotics. Accordingly, it is explained that poetry becomes true through a distinctive formation on languages. Although the communicative dimension is primary in languages that is the substance of the poetic language, the message that is the basis of communication is trivialized in poetic language. A poem is constructed in consequence of language and words formed into an artistic object by smothering the message. But, by reason of prior education or teaching, it becomes prominent in children's poetry that is evaluated as a genre of children's literature. Once sending the message is primary, the poetic features disappear. Writing in a syllabic meter and rhyming is insufficient to make some poems real poems. Hence, children do not experience in a poetic way when they read many poems written for children. Instead, they experience a communicative act that is special to non-poetic texts.This situation blocks children from developing a develop poetic and literary consciousness. For this reason, it is suggested that poems written for children should have poetic features and be produced in a way that enables children to read its new signification system poetically.

Keywords: Poetry, Children’s Poetry, Children’s Literature

\footnotetext{
* Doç. Dr., Akdeniz Üniversitesi, Eğitim Fakültesi, Temel Eğitim Bölümü, Antalya. nihatbayat@gmail.com

** Doç. Dr., Ömer Halisdemir Üniversitesi, Eğitim Fakültesi, Türkçe Eğitimi ABD, Niğde. gcetinkaya@ohu.edu.tr Bu çalışmanın bir kısmı, 19-22 Mayıs 2016 tarihlerinde İspanya Madrid'de gerçekleştirilen İBAD 2016 Sempozyumu'nda sözlü bildiri olarak sunulmuştur.
} 
Çocuk yazını alanında üstünde durulan türlerden biri şiirdir. Bir disiplin olarak çocuk yazınının şiire yaklaşımı, alanın genel ölçütlerine çoğunlukla bağımlıdır. Alanın sınırlarının belirlenmesinde çıkış noktasını çocuk ve yazın kavramları oluşturur (Oğuzkan 2000; Ciravoğlu 2000; Zengin \& Zengin 2007). Buna göre çocuk yazını, 0-14 yaş arasında bulunan insanlara yönelik oluşturulmuş yazın metinlerini kapsar. Oğuzkan $(2000,3)$ çocuk yazınını “...çocukluk çă̆ında bulunan kimselerin hayal, duygu ve düşüncelerine yönelik sözlü ve yazıll bütün eserler” olarak belirler.

Çocuk yazınının temel niteliklerinin belirlenmesi sürecinde eğitsel boyuta vurgu yapılır. Sever $(2008,17)$, “...erken çocukluk döneminden başlayıp ergenlik dönemini de kapsayan bir yaşam evresinde çocukların dil gelişim ve anlama düzeylerine uygun olarak duygu ve düşünce dünyalarını sanatsal niteliği olan dilsel ve görsel iletilerle zenginleştiren, beğeni düzeylerini yükselten ürünler" biçimindeki ifadesiyle bu disiplinin eğitim-öğretimden ayrı düşünülemeyeceğini sezdirir. Buna ek olarak, çocuk yazınının çocuğa okuma sevgisi ve alışkanlığı kazandırması gerektiğini vurgular. Dilidüzgün $(1996,26)$ de çocuk kitaplarının çocuğa sanat eğitimi veren materyaller olması gerektiğini belirtir. Bu yaklaşımlar çocuk yazınının oluşumunda çocuğu ve onun eğitimini öncelikli kılan çabalardır.

Çocuk yazını türleri, yazın sanatının türleriyle çoğunlukla benzerdir. Yazın alanındaki kitaplar genel olarak anlatı ve şiir olarak ele alınabilir. Ancak çocuk kitapları düşünüldüğünde bilgilendirici kitapları da dikkate almak gerekir. Bu durumda çocuk yazını kapsamındaki kitaplar bilgilendirici, anlatı ve şiir olarak üç ulamda ele alınabilir. Çocuk kitaplarının temel niteliklerinin belirlenmesinde çocuğa görelik ilkesine özel bir vurgu yapılır. Çocuğa görelik ilkesi çocuk okurun ilgisine, dil ve bilgi düzeyine gönderimde bulunur (Sever 2008, 17). Çocuklara yönelik hazırlanacak kitaplarda ve yazınsal ürünlerde bu ilke belirleyici bir işlev üstlenir. Dolayısıyla yazın alanında yer alan anlatı ve şiirlerin oluşturulmasında çocuğa görelik ilkesinin dikkate alınması bir gereklilik olarak sunulur.

Çocuklara yönelik yazınsal ürünlere yüklenen eğitme ve geliştirme işlevi, yazın sanatının genel yönelimleriyle tutarlılık göstermez. Eğitme ya da öğretme, çeşitli yaşantılar yoluyla oluşturulan davranış değişiklikleriyle ortaya çıkar (Sönmez 1994; Demirel 1995). Bunun için somut bir içeriğin bir materyal aracılığıyla bireye ulaşması beklenir. İlgili içeriği iletmeyi amaçlayan materyal, yine bu içeriğe göre biçimlenir. Oysa yazınsal ürünlerde oluşturulan sanatsal yapı, yaşam gerçekliğine ilişkin içeriği bastırma ve okuru oluşturulmuş sanatsal bir düzeneğe tanık kılma eğilimindedir. Okurun gerçekleştireceği bu deneyim, bir yazın ürününün varlık nedenidir. Yazın sanatı türlerinden biri olan şiirde, sanatsal deneyimin doğasının diğer türlere oranla daha açık izlenebildiği söylenebilir. Dilin şiirde aldığı sanatsal biçimin anlaşılması şiirsel deneyimin niteliğini de ortaya koyacaktır.

\section{Şiirsel dil}

Şiir tüm yazın ürünlerinin yaptığı gibi malzeme olarak dil'i seçen ve bunu şiirsel biçimde işleyen bir sanattır. Bir malzemenin sanata dönüşebilmesi için doğadaki biçiminden sanatsal bir biçem eşliğinde farklılaşması beklenir. Sesin müzikte ezgiye dönüşmesi gibi dil de şiirde iletişim odaklı kullanım biçiminden çeşitli dönüşümlerle yeni bir yapıya ulaşır. Dilin şiirde edindiği yapısal dönüşümü anlamak için doğal iletişim durumundaki yapısı dikkate alınmalıdır.

"Dil belli bir insan topluluğuna özgü, çift eklemli sesli göstergeler dizgesidir" (Vardar 1998, 75). Martinet (1998) tarafından ortaya atılan çift eklemlilik iki düzlemde gerçekleşir. Birinci eklemlenme düzleminde anlamlı birimler, yani biçimbirimler; ikinci eklemlenme düzleminde ise sesbirimler bir araya gelir (Greimas \& Courtes 1982, 17). Dil, çift eklemli niteliği nedeniyle 
diğer gösterge dizgeleri içinde en işlevsel olanıdır. Dil göstergelerinin bu çok yönlü işleyişi sanatsal amaçlar için kullanımına olanak tanır.

Topluma özgü bir yapı olan dil, o dil toplumunun üyeleri arasında ortak bir anlaşmaya göre işler. Çünkü dil "hem gösterenlerle gösterilenlerin birleşmesinden oluşan bir dizge, hem de bu birleşimin ürünü olan göstergelerle bunlarl oluşturan ve bunlartn oluşturduğu ögelerin işleyiş kurallarını içeren bir düzenektir" (Vardar 1998, 75). Dilin yapısını betimlerken Saussure (1998), kavramsal yığınla ses yığını arasında kurulan ilişkiye dikkat çeker. Buna göre dil dizgesi, anlakta yer alan kavramlarla duyusal nitelikli sesler arasındaki ilişkilenmeyle ortaya çıkar. Saussure, bu yapılanmayı aşağıdaki gibi gösterir:

Kavramlarla sesler arasındaki ilişkileri yansıtan bu düzenekte A ekseni kavramsal yığını, B ekseni ise ses yığınını karşılar. Toplumsal uzlaşım gereği kavramsal ve sessel düzlemdeki noktalar arasında değişmez bağlantılar kurulur. Bağlantıları belirleyen kurallar aynı toplumun bireyleri tarafindan bilinir. Bu bilgi aracılığıyla bireyler gücül bir dil bilgisine sahip olur. Gücül bilgi daha sonra Chomsky

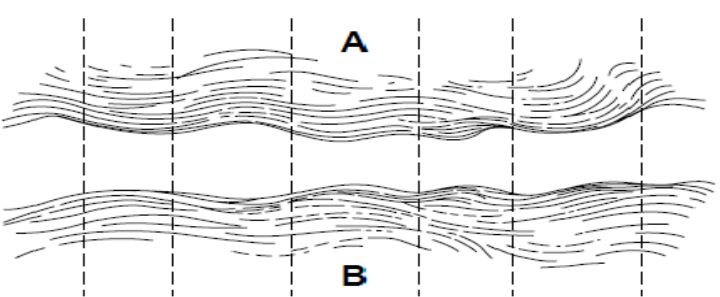

Fig. 1. Dilde ses ve anlam düzlemlerinin ilişkisi (Saussure 1998, 168) (1999) tarafından dilsel edinç olarak terimleştirilir. Dilsel edinç, karşılaşılan dil yapılarının nasıl anlaşılacağını belirleyen yorumları üretmeye olanak tanır. İletişimi sağlayan dil, bu edinçle işlev kazanır.

Bununla birlikte, dilin toplumsal iletişimdeki kullanımını yöneten soyut kurallar dilsel birimleri başka türden kullanımlara kapatmaz. Dil, sanatsal bir yapının malzemesi olarak kullanılacağı zaman göreceli olarak bu kuralların dışına taşınabilir. Çift eklemli yapısı nedeniyle dili oluşturan birimler ve birimcikler toplumsal uzlaşımda olduğundan farklı biçimlerde bir araya gelebilir. Şiir dilinin yapısı, dilin bu boyutu üstüne temellenir. Bireylerdeki dilsel edinç, dilin kazandığı şiirsel biçimleri anlamada işlevseldir. Şiirsel dile bu açıdan bakıldığında dilsel edinçle çözümlenebildiği, ancak doğal dil işleyişinin ötesinde konumlandığı söylenebilir.

Doğal dil ile şiir dili arasındaki ayrımı açık bir biçimde anlayabilmek için üç farklı noktadan bakmakta yarar var: Dilsel işlev, göstergeler ve töz-biçim. Bu terimler çağdaş dil kuramlarının temellenmesinde dil dizgesinin betimlenmesine ilişkin çıkış noktalarını oluşturur. Doğal dilin işleyişini ve yapılanışını yansıtan bu terimlerin şiir dilindeki niteliği aradaki farkın anlaşılmasına katk1 sağlayacaktır.

Dilin belli biçimdeki kullanımı onun şiirsel işlevini açığa çıkarır. Şiirsel işlev, Jakobson'un (1982) belirttiği gibi iletişim düzeneğinde yer alan ileti, gönderici, alıcl, gönderge, kod ve kanal birimlerinin iletiyle kurduğu ilişkiye göre ortaya çıkan dilsel işlevlerden biridir. Şiirsel işlev iletinin diğer birimlere değil, kendi üstüne yönelik olması sonucunda belirir. Bu işlevin belirgin özelliği, iletişimsel dilin özü olan içeriğin bastırılmasıdır. İçeriğin bastırıldığı durumlarda, alıcıya bir bilgi gönderimi öncelikli amaç olmaktan çıkar. Bilgi gönderimi amacının yerini, oluşturulan içeriğin yapılanma biçimi alır. Şiirsel işlevde alıcının dikkatini iletinin yapılanma biçimine çekmek için doğal dilde kimi yapısal dönüşümler gerçekleştirilir.

Dilin şiirsel işlevinin etkin olduğu yapılar diğer dilsel işlevlerdeki yapılara oranla belirgin bir fark taşır: Çift eklemli yapısı gereği bir araya gelen birimler, aralarındaki ayrımlar nedeniyle fark edilir. Ayrımlar dilsel birimlerin işlerlik kazanmasına olanak tanır. İleti oluşturma ve iletişim kurma bu ilkeye dayanır. Oysa şiirsel işlev dilsel birimler arasında ayrımlar değil, benzerlikler 
üretir. Benzerlikler, dilin olağan kullanımının bastırılması ve ona yeni bir yapılanma biçimi kazandırılması sonucunda oluşur. Jakobson $(1982,170)$, bu nedenle şiirsel işlev için "eşdeğerlik ilkesini seçme ekseninden birleştirme eksenine aktarır" belirlemesini yapar. Buna göre şiirsel işlevin, dilin olağan kullanımının dayandığı temel ilkeyi sarsarak ortaya çıktığı söylenebilir.

Seçme ve birleştirme eksenleri, dilsel yapıların oluşumundan önceki üretim işlemlerine gönderimde bulunur. Buna göre bir tümce üretileceği zaman, iletişimsel amaca uygun olarak çeşitli birimler arasından seçimler yapılır ve bu seçimler birleştirme ekseninde birbirine eklemlenir. "Çocuk, uzaklaşan trene üzülerek baktı" tümcesinin oluşumu, seçme ve birleştirme ekseninde aşağıdaki biçimde gösterilebilir:

Tablo 1. Seçme ve Birleştirme Ekseni

\begin{tabular}{|c|c|c|c|c|}
\hline \multicolumn{5}{|c|}{ Birleştirme ekseni } \\
\hline$\Xi$ & Çocuk, & uzaklaşan trene & üzülerek & baktı. \\
\hline 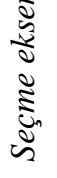 & $\begin{array}{l}\text { Zavallı } \\
\text { Çocukcağız } \\
\text { Öksüz } \\
\text { Rifat }\end{array}$ & $\begin{array}{l}\text { gittikçe küçülen vagona } \\
\text { gözden irayan kara kutuya } \\
\text { silinen kara demire } \\
\text { siste yiten şimendifere }\end{array}$ & $\begin{array}{l}\text { iç sıkıntısıyla } \\
\text { kasvetle } \\
\text { kederle } \\
\text { yalnızlık duygusuyla }\end{array}$ & $\begin{array}{l}\text { izledi. } \\
\text { bakakaldı. } \\
\text { kilitlendi. } \\
\text { daldı. }\end{array}$ \\
\hline
\end{tabular}

$\mathrm{Bu}$ tümcenin oluşumunda belli bir konuma gelebilecek birimler arasında benzerlikler (eşdeğerlikler) söz konusudur. Örneğin zavall, çocukcağız, öksüz ve Rlfat birimleri benzer işlevdedir. Seçme ekseninde yer alan birimler ile diğer eksenlerdeki birimler arasında ayrımlar bulunur. Böylece dilsel bir kullanımda benzerlik bağıntısıyla ilişkilenen birimler arasından seçimler yapılır ve bunlar birleştirme eksenine ayrımlarla yansır. Ortaya çıkan tümcenin birimleri, aralarındaki ayrımlar nedeniyle iletişimsel bir işlevi gerçekleştirir. Buna göre yukarıdaki tablodan yapılacak farklı seçimler, aynı anlamı yansıtan ancak farklı değerlere sahip birçok tümcenin üretilebileceğini gösterir. Şiirsel işlevdeki dil kullanımında yapılacak seçimler ise ayrımlar değil, benzerlikler üretmek için gerçekleştirilir.

Şiirsel işlev, benzerlik ilkesini sessel ve anlamsal eksenlerde yaratır. Şiir dilinde ses ve anlam birimleri, hem kendi içlerinde hem birbiri arasında doğal dilden ayrışarak olabildiğince benzer yapılarda üretilme eğilimindedir. Ancak birçok şiirde genellikle bu eksenlerden birinin daha baskın olduğu görülür. Benzerliğin izlenebildiği eksenlere göre Cohen şiirleri ses şiiri, anlam şiiri, ses+anlam şiiri olarak üç türde ele alır (Yalçın 2003, 92). Aşağıdaki dizelerde bulunan ses ve anlam benzerlikleri şiirsel işlevin doğasını açık biçimde yansıtır:

"boğulduğum son bir su daha var

vurur gövdemi klyına atar"

(Anlar, Akif Kurtuluş)

$\mathrm{Bu}$ dizelerde geçen dilsel birimler belli bir içeriği iletmek için kullanılmamış, bunun yerine ses ve anlam bakımından aralarında kurulan benzerlikler yoluyla şiirsel dili yapılandırmıştır. Dize sonlarında italik yazılan sesler arasında şiirsel bir koşutluk kurulduğu söylenebilir. Aynı biçimde yine sözdizimsel yapılarla denkleştirilen boğulma ve vurma birimleri ile su ve kıyı birimleri arasında anlamsal açıdan bir koşutluk yaratılmıştır. Bu dizelerde oluşturulan ses ve anlam koşutlukları dilin şiirsel işlevde kullanımının sonucudur.

Doğal dil ile şiir dili arasındaki farklardan bir diğeri dil göstergelerine ilişkindir. Doğal dilde dil göstergeleri, bir gösteren ve gösterilen birleşiminden oluşan anlamlı en küçük birimlerdir. Buna göre kedi göstergesi "k.e.d.i" ses diziliminden oluşan bir gösteren ile "/kedi/” kavramından oluşan bir gösterilenin birleşimi sonucunda yapılanır. Gösteren ile gösterilen arasındaki ilişki nedensizdir ve toplumsal uzlaşıma dayalıdır. Başka bir deyişle, /kedi/ kavramının "k.e.d.i" ses 
düzeneğiyle anlatılmasının mantıklı bir nedeni yoktur. Buna karşın şiirsel göstergede gösterenle gösterilen arasındaki ilişki çoğunlukla nedenlilik ilkesiyle belirlenir. Şiirde bir içeriğin şiirsel amaçla ifadesinde gösteren ve gösterilenler arasında belli bir mantığa dayanan kabul edilebilir ilişkilendirmeler üretilmeye çalışılır. Aşağıdaki dizelerde yer alan şiirsel göstergeler bu türden bir ilişkilenmeyle üretilmiştir:

\section{"Bir ilkokul bahçesi geçiyordu Clvıl cıvll sulardan” (Bir Çiçek II, Cemal Süreya)}

$\mathrm{Bu}$ dizelerde kullanılan ilkokul bahçesi, bir gösteren olarak gerçek bir ilkokul bahçesini değil, belli bir su akışında beliren sesleri aktarır. Dizede dolaylı biçimde gönderimde bulunulan okul bahçesindeki öğrencilerin sesleri ile suyun akışındaki sesler arasında şiirsel bir koşutluk yaratılmıştır. Bu iki ses çeşitli açılardan birbiriyle ilişkilenir. Özellikle coşkulu niteliği nedeniyle olumlu bir değer olarak sunulması, her iki sesin de sürekliliği ve anlamlı bütünlükler olarak değil, ancak bir yığın olarak kulağa ulaşması şiirsel koşutluğun dayanaklarıdır. Bu iki birimden biri (okul bahçesi) diğerinin (sudaki ses) göstereni durumuna gelir. Bu ilişkilenme toplumsal dilde bulunmayan, yalnızca bu şiirde geçerliliği olan şiirsel bir göstergeleşmedir.

Dil göstergeleri şiirsel bir göstergeye dönüşürken sözdizimsel yapılar aracılığıyla doğal dilde yan yana gelemeyecek farklı göstergelerle de ilişkilenir. Göstergeler, şiirsel yapılar içinde doğal dilde sahip olmadıkları kimi nitelikler kazanabilir. Genellikle belli bir seçim ekseninde yer alan bir işlev, bu yolla başka bir eksendeki göstergeye aktarılabilir. Cemal Süreya'nın aşağıdaki dizesinde böyle bir durum göze çarpar:

\section{"Gür ve coşkun bir günışığı dadanmış pencereye”}

Bu dizede günışı̆̆g göstergesi bulunduğu eksen gereği parlaklık, aydınlık, doğmak, çekilmek, vd. anlambirimciklerle tanımlanırken dadanma ve pencere göstergeleri nedeniyle bu boyutlar ortadan kalkar; bunun yerine kuşlara ilişkin anlambirimciklerle donanır. Bu bağıntı şiirsel işlevle olanaklı duruma gelir. Dizede bir içeriği aktarmak değil, bu iki gösterge arasında kurulan bağıntı önceliklidir. Kuşlara ilişkin seçme ekseninde yer alan tüm ayrıntıların günışığı'na yüklenmesi, aynı yerde gözlemlenebilen iki gerçeklik olmaları bakımından nedenlidir. Ancak doğal dilde kabul edilebilir değildir. Bunun yanında dilsel edinçle çözümlenebilen bir kullanım olması nedeniyle de şiirsel bir birimdir. Şiirin okunması sürecinde, okurun deneyimlemesi beklenen bir haz kaynağıdır.

Şiirsel göstergelerin doğal dil göstergelerinden ayrılan bir diğer yanı gösterenlerin önem kazanmasıdır. Doğal dil göstergelerinde duyusal boyutu oluşturan ses ya da yazı (gösteren), kavrama (gösterilen) taşıyıcılık yapma dışında herhangi bir işleve sahip değildir. Bu işlevi yerine getirdikten sonra unutulma eğilimindedir. Ancak şiirsel göstergede ses ya da yazı zorunlu bir birim durumuna gelir. Anlamsal düzlemdeki biçimlenme, gösterenlere bağımlı olarak işler. Dolayısıyla göstergenin ses ya da yazıdan oluşan duyusal boyutu şiirde yitip gitmez. Bu nedenle bir şiir ya da dize, doğal dilin tersine başka sözcüklerle yeniden ifade edilemez.

Şiir dili ile doğal dil arasındaki ayrımın üçüncü dayanağı ise başka bir tözden üretilmesiyle ilgilidir. Ses ve anlam düzlemlerinin ilişkilenmesiyle işleyen doğal dilde, doğadaki seslere çeşitli biçimler verilerek bir dilin ses dizgesi üretilir. Aynı biçimde kavramsal gerçekliğe ilişkin yapılan kesitlemeler de dilsel anlamları yaratır. Böylece kavramlar ve sesler, dilin tözünü oluşturur. Bu tözden üretilmiş biçimler dil dizgesini yapılandırır. Oysa şiirsel dilin tözü, ses ve anlam düzlemlerindeki doğal dilin biçimleridir. Her bir dil göstergesi, şiire şiirsel bir biçim edinerek girer. Doğal dilde nasıl töz yerine biçimler belirleyici ise şiir dilinde de biçimler önceliklidir. Şiir dilinin tözü doğal dil olduğundan şiirsel söylemde doğal dil yalnızca üstünde biçimlenme 
yapılacak bir materyal niteliği taşır. Doğal dilde zorunlu bir öğe durumundaki ileti, şiir dilinde önemini kaybeder. Şiir olsun diye yazılan bir betikte iletişimsel boyut (ileti) baskınsa şiirsel bir biçimlenmenin yapılanamamış olduğu söylenebilir.

Hjelmslev doğal dilin töz ve biçim açısından oluşumunu bir figür ile göstermiştir (Yücel 2005, 53). Aynı figür Yalçın $(2003,299)$ tarafından şiirsel göstergenin yapısını göstermek için uyarlanarak ve ayrıntılandırılarak kullanılmıştır. Aşağıda doğal dil ile şiir dilinin töz ve biçim açısından görünümü bu figürlere dayanarak verilmiştir:

Doğal dil

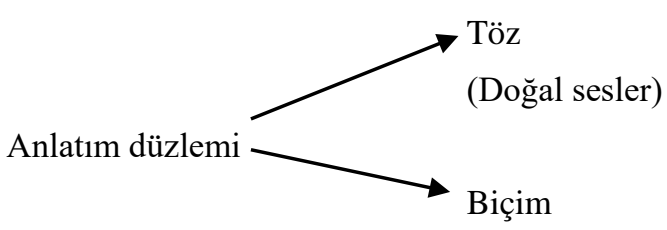

(Dilsel sesler)

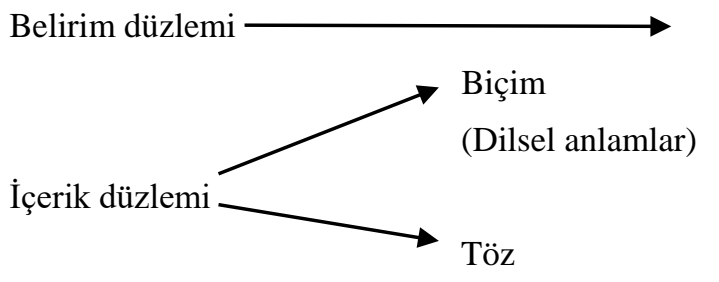

(Kavramsal dünya)
Şiir dili
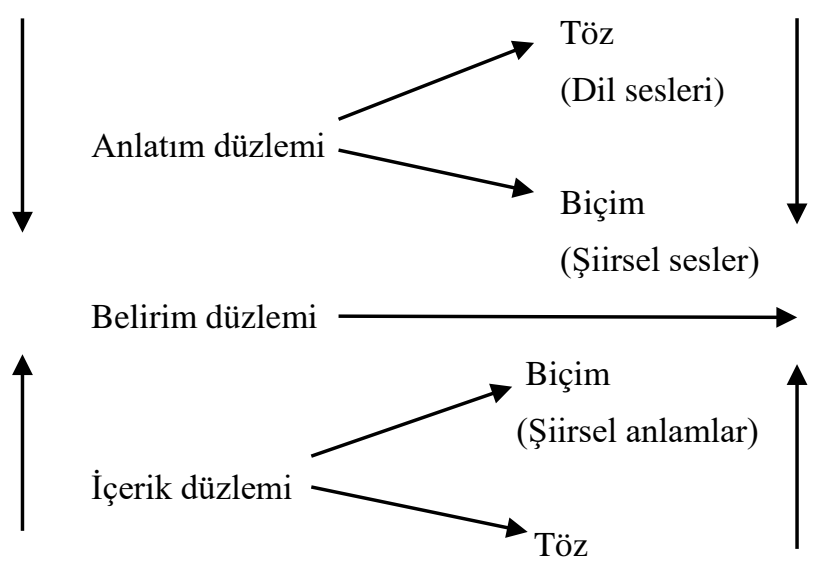

(Dilsel anlamlar)

Fig. 2. Doğal ve şiir dilinin töz ve biçim açısından görünümü

$\mathrm{Bu}$ figürlerden birincisinde doğal dilin anlatım ve içerik düzlemlerinde gerçekleşen yapısal oluşum gösterilmiştir. İkinci figürde ise şiir dilinin benzer bir yapılanmayla oluştuğu, ancak bu yapılanmanın töz ve biçiminin doğal dildekinden farklı olduğu vurgulanmıştır. Şiir dilindeki töz ve biçimin daha açık anlaşılması için aşağıdaki dizeye bakılabilir:

\section{"Yokluğuma kar biriktiren yazla birlikte" \\ (Ölümün Konumu, Edip Cansever)}

$\mathrm{Bu}$ dizede yer alan her bir gösterge doğal dilde kullanılan birer sözcüktür. Her birinin sözlükte ve çeşitli bağlamlarda bir anlamı ve kullanım değeri vardır. Ancak bu dizede, sözcükler şiirsel bir biçimlenme sonucunda şiirsel göstergeye dönüşmüştür. Dönüşüm, ağırlıklı olarak anlamsal eksende gerçekleştirilmiştir. Göstergelere öncelikle farklı seçme eksenlerinin işlevleri yüklenmiştir. Bir mevsim olan yaz'ın biriktirme eylemini gerçekleştirmesi böylesi bir işlemin sonucudur. $\mathrm{Bu}$ göstergeler, aralarında bakışımlı ilişkiler oluşturacak biçimde sözdizimsel bir yap1 üstüne dağılmıştır. Buna göre yokluk-biriktirme ve kar-yaz birimleri arasında örtük bir karşıtlık kurulmuş ve bu karşıtlıklarla geometrik bir bakışım üretilmiştir. Bu karşıtlık Greimas'ın (Yücel 2005, 136) göstergebilimsel dörtgeniyle açımlanabilir.

Anlamlamanın derin yapısındaki bağıntıları betimlemek için kullanılan göstergebilimsel dörtgen, bir anlam biriminin kendisi olmayan bir birime ve karşıt iki anlambirimciğe göre belirlenebileceğini ortaya koyar. Buna göre yukarıdaki dizenin içeriğini oluşturan anlamsal yapı yokluk-biriktirme göstergeleri temelinde şöyle gösterilebilir: 
Bu dörtgene göre yokluk-varlık birimleri karşıt, tüketmebiriktirme birimleri alt karşı1, yokluk-biriktirme ve varlıktüketme birimleri çelişik, yokluk-tüketme ve varlı-biriktirme birimleri ise içerim ya da bütünleyim bağıntısı içindedir. Greimas'in ortaya koyduğu göstergebilimsel çözümleme, anlamın oluşumunu açıklaması bakımından

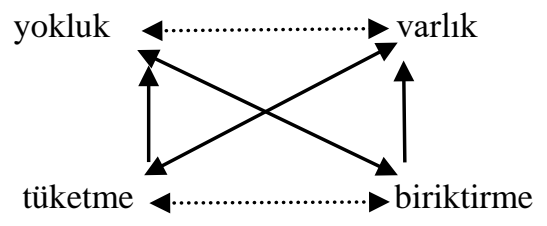

Fig. 3. Göstergebilimsel dörtgen işlevseldir. Şiirde bazı sözcüklerin içerdiği göstergebirimcikler (en küçük anlamsal birim) bu dörtgenle açıklanır. Böylesi bir çözümleme, söylemin yüzey yapısında çelişkili görünen sözcüklerin hangi bağıntılarla bir araya gelebildiğinin, başka bir deyişle nasıl yerdeş olduklarının anlaşılmasını sağlar.

Yukarıdaki dizede doğal dilin hem göstergeleri hem sözdizimsel işleyişi şiirsel işlev için yeniden biçimlendirilmiştir. Dil göstergeleri, içerdikleri göstergebirimciklere dayalı olarak yeniden değerlendirilmiştir. Bu dizede üretilen şiirsel birimlerin tözü, doğal dilin biçimleri olmuş ve şiirsel biçimlendirme doğal dili ikincil bir değerde tutmuştur. Başka bir deyişle, doğal dil bu dizede işlevini yitirmiştir. Doğal dilin göstergeleri ve kuralları, bir içeriği aktarmak yerine şiirsel birer alım nesnesine dönüşmüştür.

\section{Çocuk Şiiri}

Çocuk şiirlerinin birçoğu yukarıda ana hatlarıyla anlatılan şiirsel biçimlenmeden yoksundur. Bunun nedeni, çocuk yazınının genel amaçlarına dayanır. Çocuk yazını, çocukları eğitmeyi ve onları geliştirmeyi amaçlar (Uzuner Yurt 2011; Tüfekçi-Can 2014). Çocuk şiiri yazan birçok şair bu amacı bilinçli olarak seçer. İbrahim Aleattin, Ali Ulvi, Ziya Gökalp, Tevfik Fikret gibi şairler yazını bir araç olarak kullanıp çocukları eğitmeyi, onlara bir yaşam bilgisi iletmeyi amaçlamışlardır (Sever 1996, 31). Bu anlayışla üretilen çocuk şiirlerinde içerik (konu, tema) ön planda tutulmuştur. Kimi çalışmalarda (Canatak 2011; Aydemir 2014), çocuk şiirlerinin temalarına göre sınıflandırılması bu anlayışın bir sonucudur. İçeriği öne çıkarma kaygısı, betiklerdeki şiirselliğin yapılanamamasına neden olmuştur.

İbrahim Aleattin'in çocuklarda "vatan sevgisi” oluşturmayı amaçladığı Vatan adlı şiirinden alınan aşağıdaki dizeler bu bakımdan dikkate değerdir:

"Bir fena söz işitirsen iyi bil:

Beğenmeyen bizi Osmanlı değil.

Bir yabanci gelir seni kandirir,

Ĕ̆er derse bu memleket fenadır.

Darll yavrum onu sakın söyletme.

Topră̆ını hainlere çiğnetme!"

Bu dizelerde ne ses bakımından ne de anlam bakımından şiirsel bir biçimlenme vardır. Dizeli olarak yazılması veya birkaç belirsiz uyak kullanımı şiirsel dili üretmede yeterli değildir. Levin $(1977,9)$ şiirsel söylemde biçimle anlamın yüksek düzeyde birleşimine vurgu yaparken iletişimsel içeriğin şiirsel biçimlenmenin önüne geçmemesi gerektiğini sezdirir. Oysa yukarıdaki dizelerde çocuk okura bir yaşam bilgisi verilmektedir. Şiirsel bir yapılanma gerçekleşmediğinden betiğin okunmasında şiirsel bir deneyim de oluşmayacaktır.

Çocuk şiirlerine ilişkin bir diğer yanılgı ölçü, uyak, dize gibi çeşitli anlatım araçlarının şiir için yeterli görülmesidir. Oysa dizeli anlatım şiirsel dilde bir zorunluluk değildir. İşlevi, şiirsel dilin yapısının algılanabilirliğini görece artırmaktır. Şiirsel dil, düzyazı biçiminde de oluşturulabilir. Dilin şiirsel işlevi, betik biçimlerinin ötesinde dilin yapısal boyutlarında gerçekleştirilen dönüşümlerle üretilir (Yalçın 2003, 34-35). 
Ceyhun Atıf Kansu'nun çocuk şiirleri arasında değerlendirilen Çocukluk Aşkı adlı şiirinde geçen aşağıdaki dizeler, şiirselliğin yapılanamaması ve ileti aktarımını öncelemesi bakımından çarpıcı bir örnektir:

"Satılır mı zengin bir oyuncakçıda söyle, Anne, dün okuduğun masaldaki güzel klz? Yeter, altın bir kalbin olsun, Tanri'dan dile, Bütün zenginliğimi verir onu alırlz!"

$\mathrm{Bu}$ dizelerde iletilen içerik düzyazı biçiminde de aktarılabilir. Amaç bir bilgi aktarımı ise söylemin biçimini şiire öykünerek oluşturmak iletişim açısından verimli bir çaba değildir. Doğrudan konuşur gibi içeriği aktarmak daha anlamlı olabilir. Ancak şiirsel bir yapı amaçlanmışsa okurun betikteki içeriği aşması gerekir. Çünkü kullanılacak içerik şiirsel dönüşümle başkalaşacaktır.

Çocuk şiirlerinde çoğunlukla göz ardı edilen bu duruma karşın belli ölçüde şiirselliğe sahip betikler de üretilmiştir. Salih Mercanoğlu'dan alınan aşağıdaki şiir bunun bir örneğidir:

\author{
$D \ddot{U} S \underline{U} N \ddot{U}$ \\ "Anneciğim, \\ Biliyorum sofrada \\ Her şey var. \\ Ama aç dę̆ilim \\ Koca bir bulut yedim \\ Az önce. \\ A ̆gzımı sildi rüzgar" Salih Mercanoğlu
}

$\mathrm{Bu}$ betikte şiirsel işlevin baskın olduğu söylenebilir. Anlamsal eksende yapılan biçimlemede, annelerin çocuklarına yemek yedirmeye uğraştığı durumlarda kullandığı bir söylem biçimi tözü oluşturmuştur. Ancak bu biçimde özellikle bulut-yeme ve rüzgar-silme birimleri arasında şiirsel bir ilişkilendirme yapılmıştır. Doğaya ilişkin iki birimin (bulut, rüzgar), yiyecek ve anne göstergelerine ilişkin anlambirimciklerle donatılmış olması şiirsel işlevin bir sonucudur. Bunun yanında doğa ve anne birimleri arasında koruyuculuk, kollayıcılık, besleme, vd. boyutlar arasındaki koşutluk söz konusu şiirselliği artırmaktadır. Öyle ki birçok kültürde anne çocuğu, doğa insanlığı var eden temel varlıklar olarak algılanır. Yukarıdaki diğer dizelerin gelişimi, bu şiirsel yapıyı sunmak içindir.

\title{
Sonuç
}

Yukarıdaki açıklamalar şiir dilinin doğal dilden işlev, gösterge yapısı ve töz-biçim açısından önemli ayrımlara sahip olduğunu ortaya koymuştur. Şiir dilinin kendine özgü yapısı, şiirsel betiklerin niteliğine de işaret eder. Bu bakımdan şiiri doğal dil ürünü olarak ele alıp anlamlandırmak ve içeriğinden bir yaşam gerçekliğine ulaşmaya çalışmak şiirin doğasına uzak bir çabadır.

Doğal dilin yapısal özellikleriyle oynayarak kendini yapılandırma eğiliminde olan şiir dilinin bunu her şiirde farklı düzeyde gerçekleştirebildiği söylenebilir. Bu nedenle üretilmiş şiirler birbirinden farklı düzeylerde şiirselliğe sahiptir. Bu durum, şiir olsun diye yazılmış kimi şiirlerin şiirsel yapıya erişememiş olabileceğine de işaret eder. Düzeyleri farklı olsa da bir betiğin şiir olabilmesi yeni bir anlamlama dizgesi kurabilmiş olmasına bağlıdır. Şiirsel bir dizge oluşturamamış betiklerin kolay şiir olarak düşünülmesi, onların okuru bir dünya gerçekliğine taşımasıyla ilişkilidir. Bu nitelik ortada bir şiirin bulunmadığının göstergesi de olabilir, çünkü 
şiirsel bir deneyim yerine bir yaşam gerçekliğine ulaş1liyorsa şiirselliğin yoksunluğundan kaynaklı iletişimsel bir durum var demektir. Bu açıdan bakıldığında eğitme-öğretme amaçlı çocuk şiirlerinin çoğunlukla şiirsellikten yoksun, ölçü ve uyak gibi şiir dışı birimlerin kullanıldığı iletişimsel işlevli dil ürünleri görünümünde olduğu söylenebilir.

Diğer bir nokta da çocuk yazını kavramına bağlı olarak yalnızca çocuklara özgü şiir yazma çabasıdır. Bu şiirler aynı anlayışla bir öğüt ya da bilgi ileten, kolayca anlaşılabilen ve gereği yapılabilecek (!) türden şiirlerdir. Oysa doğal dil, şiirsel işlevle biçimlenip şiir olmayı başarabilmişse üstünde biçimleme yaptığı içerikten uzaklaşmış demektir. Bunun yanında şiirleşmiş bir betik yalnızca çocuklara değil, şiire ilgi duyan herkese haz verebilir. Bu nedenle çocuklarda geçerliliği olan ancak yetişkinleri etkilemeyen şiir, şiirsel ölçütler açısından olanaklı görünmüyor. Sonuç olarak şöyle bir ikilem söz konusudur: Bir betik yalnızca çocuklara yönelikse şiir değildir, şiir olmayı başarmış bir betik ise herkese yöneliktir. Bu bakımdan, çocuk şiiri yazan kişilerin çocuklara bir şey iletme kaygısının şiirsel dilin yapısı açısından geçersiz olduğu söylenebilir. Eğitsel amaçlarla şiirlerin kullanımına ilişkin değerlendirmeler şiirin içeriği üstünden yapıldığında şiir adına yanlış bir noktaya varılabilir. Ancak şiirin, üstünde biçimleme yaptığı içerik nedeniyle değil, yalnızca işleviyle dile ilişkin bir duyarlılık kazandırabileceği söylenebilir. 


\section{KAYNAKÇA}

Aydemir M. (2014). "Ceyhun Atuf Kansu'nun Şiir Sanatı ve Şiirinde Çocuk”. A.Ü. Türkiyat Araştırmaları Enstitüsü Dergisi 51 (2014) 211-228.

Canatak A. M. (2011). "İbrahim Alâettin'in (Gövsa) Çocuk Şiirleri Adlı Eserinin Çocuk Edebiyatındaki Yeri”. Turkish Studies 6/2 (2011) 287-296.

Ciravoğlu Ö. (2000). Çocuk Edebiyatı. İstanbul 2000.

Chomsky N. (1999). “Edinç-Edim”. XX. Yüzyll Dilbilimi (1999) 272-293. İstanbul.

Demirel Ö. (1999). Öğretme Sanatı. Ankara 1999.

Dilidüzgün S. (1996). Çağdaş Çocuk Yazını. İstanbul 1996.

Greimas A. J. \& Courtes J. (1982) Semiotics and Language an Analytical Dictionary. Bloominton 1982.

Jakobson R. (1999). “Dilbilim ve Yazınbilim”. Yazko Çeviri 8 (1999) 163-170.

Levin S. R. (1977). Linguistic Structures in Poetry. New York 1977.

Martinet A. (1998). İşlevsel Genel Dilbilim. İstanbul 1998.

Oğuzkan A.F. (2000). Çocuk Edebiyatı. Ankara 2000.

Saussure F. de (1998). Genel Dilbilim Dersleri. İstanbul 1998.

Sever S. (2008). Çocuk ve Edebiyat. İzmir 2008.

Sever S. (1996). Tevfik Fikret ve Çocuk Şiirleri. Ankara Üniversitesi Eğitim Bilimleri Fakültesi Dergisi 29/1 (1996) 31-47.

Sönmez V. (1994). Program Gelişstirmede Öğretmen El Kitabı. Ankara 1994.

Tüfekçi-Can D. (2014). Çocuk Edebiyatına Giriş. Konya 2014.

Uzuner-Yurt S. (2011). “Çocuk Yayınları.” Kuramdan Uygulamaya Çocuk Edebiyatı (2011) 67-76. Ankara. Vardar B. (1998). Açıklamalı Dilbilim Terimleri Sözlüğü. İstanbul 1998.

Yalçın M. (2003). Şiirin Ortak Paydası: Şiirbilime Giriş. İzmir 2003.

Yücel T. (2005). Yapisalcllık. İstanbul 2005.

Zengin A. Y. \& Zengin N. (2000). Eğitim Fakülteleri İçin Çocuk Edebiyatı. İstanbul 2000. 